\title{
Nutrition as a Vital Sign: Progress Since the 1990 Multidisciplinary Nutrition Screening Initiative and Opportunities for Nursing
}

\author{
Kelsey Watson ${ }^{1 *}$, Marie Farrell ${ }^{2}$, Mary Beth Arensberg ${ }^{3}$ and Johanna Dwyer ${ }^{4}$
}

${ }^{1}$ Friedman School of Nutrition Science and Policy, Tufts University and Tufts Medical Center, USA

${ }^{2}$ Professor, Human and Organizational Development, Fielding Graduate University, USA

${ }^{3}$ Director of Health Policy and Programs, Abbott Nutrition Products Division of Abbott, USA

${ }^{4}$ Senior Scientist, Jean Mayer Human Nutrition Research Center on Aging at Tufts University and Professor, USA

*Corresponding author: Kelsey Watson, Tufts University, Boston, MA, United States, Tel: +1 317850 0144; E-mail: Kelsey.watson@tufts.edu; kels.wats75@gmail.com

Received date: November 1, 2014, Accepted date: December 23, 2014, Published date: January 05, 2015

Copyright: () 2015 Watson $\mathrm{K}$, et al. This is an open-access article distributed under the terms of the Creative Commons Attribution License, which permits unrestricted use, distribution, and reproduction in any medium, provided the original author and source are credited.

\begin{abstract}
Vital signs provide critical information about health and help form the baseline for clinical care. Twenty years ago, the Nutrition Screening Initiative posed nutrition screening as a vital sign for older Americans but this has still not occurred. Nursing is on the frontline for monitoring as well as working to improve nutrition intake in collaboration with dietitians and other healthcare professionals. This article describes the importance of malnutrition screening, key indicators of elder well-being, and how the older American population has changed in the last few decades. The article also chronicles the multidisciplinary Nutrition Screening Initiative, its accomplishments, challenges, and new developments including new screening data collection instruments and the frailty index. Other developments described are the Alliance to Advance Patient Nutrition's intervention framework and documentation of the economic value of nutrition intervention. Opportunities and next steps for nurses to help malnutrition screening become a vital sign are identified. These include the need to make malnutrition screening and intervention part of the core training for nurses. In the hospital setting, the Joint Commission requires that all patients be screened for malnutrition within 24 hours, however malnutrition interventions are often lacking. Thus another opportunity is for malnutrition measurement and documentation to be developed as a summative measure and included as part of the standardized nursing language, with a specific section in the Electronic Health Record. Becoming part of national health goals, such as the Healthy People 2020 objectives, is an additional important step for the evolution of malnutrition screening as a vital sign as is integrating malnutrition screening and intervention into healthcare incentives, including the Patient Protection and Affordable Care Act, transitions of care, and community intervention. Finally, committing funding for malnutrition screening, such as through reauthorization of the Older Americans Act, and gaining key learning from international experiences are important.
\end{abstract}

\section{Introduction}

Vital signs are defined as a measurement of the body's most basic functions-including temperature, respiratory rate, pulse, and blood pressure-that provide critical information about a person's health and help form the baseline for clinical care. Over 20 years ago, an article posed the question of whether nutrition screening should be a vital sign for older Americans and outlined the progress of the Nutrition Screening Initiative (NSI) in helping to achieve this [1]. While the NSI was designed to address elderly in the US, burgeoning numbers of older adults around the globe could also benefit from routine malnutrition screening and intervention adapted to their unique national health structures and population characteristics. More recently, malnutrition screening has been proposed as the seventh vital sign for oncology care [2,3]. Much has changed in the decades since the original suggestion of nutrition screening as a vital sign. If it is indeed a vital sign for older Americans, it should be a routine part of healthcare, and when it reveals the need for nutritional interventions, it should be part of standard healthcare interventions. Nursing plays a critical role in taking vital signs. Nursing is also on the frontline for monitoring as well as working to improve nutrition intake, in collaboration with dietitians and other healthcare professionals [4].
In defining the opportunity for nurses to help malnutrition screening become a vital sign, this article describes the importance of malnutrition screening and the ways in which the older American population has changed in the last few decades; it also chronicles the NSI through its accomplishments, challenges that remain, progress, and new developments in the intervening 25 years. The article concludes with recommended next steps to establish a vital sign, steps for patients/families, healthcare practitioners-especially nurseshealthcare systems and policy makers to take, in light of the current state of malnutrition screening and intervention practices.

\section{Importance of Malnutrition Screening of Older Adults}

Nurses may observe that older adults differ from younger adults in many ways that may affect their nutritional status to varying degrees, and the older the group, the more pronounced are these differences. These include factors that may affect dietary intake such as decreased appetite, thirst, vision, taste, smell, and chewing ability. With aging, many alterations occur in digestive, gastroenterological, liver, pancreatic, and kidney functions, and alterations in other organ systems, such as the heart or lungs, may affect both intake and metabolism. Also, changes in cognitive function and body composition occur with aging, often marked by decreased lean tissue and bone mass and increased fat in tissue [5]. Considerable variability 
Citation: Watson K, Farrell M, Arensberg MB, Dwyer J (2014) Nutrition as a Vital Sign: Progress Since the 1990 Multidisciplinary Nutrition Screening Initiative and Opportunities for Nursing. J Nurs Care 4: 224. doi:10.4172/2167-1168.1000224

Page 2 of 15

is evident at all ages in the presence and severity of these changes and the extent to which they are preventable or ameliorable or secondary to poor nutritional status, while the presence of these factors puts some older adults at a disproportionately high risk for malnutrition.

Sub-clinical malnutrition can arise because it is confused with aging and thought by caretakers to be inevitable [6]. Unfortunately, many signs and symptoms of malnutrition are also suggestive of disease processes, making their interpretation complicated, as they are often nonspecific [7]. Although, the presence of malnutrition may sometimes be due to pathological processes that cannot be ameliorated by nutritional means, other forms of malnutrition, once identified, can be treated. Thus, efforts should be directed toward screening, prevention, and treatment of malnutrition whenever it is possible [7].

Malnutrition screening of older adults is important today for maintaining or improving health status, and it aligns well with the current, national focus on preventive care. The 2010 Patient Protection and Affordable Care Act (ACA) outlined several preventive services to be covered by insurance, making them available to the majority of Americans [8,9]. Implementation of malnutrition screening and intervention for older adults also aligns well with the goals of the new payment systems that are now linked to health outcomes [10].

\section{Older American Population, Morbidity, Mortality, and Functional Status Estimates}

The past two decades have brought many social and demographic changes in the elder population as well as in healthcare services. Implementing these changes provides opportunities for nurses to help make malnutrition screening a vital sign. Experts at the Centers for Medicare \& Medicaid Services (CMS) indicate that the US national health care expenditures rose from approximately $\$ 724$ billion in 1990 to $\$ 1,377$ billion in 2000 and are projected to be $\$ 3,130$ billion. This represents a change from 12 percent of gross domestic product (GDP) in 1990 to 18 percent of GDP today. Aging of the population is a major reason for this growth, since Americans over 65 years of age are growing in numbers and they use twice the medical services as those under 65 [11]. A number of positive changes have occurred in the characteristics of the US older adult population in the last 20 years, yet they remain at risk for malnutrition. Table 1 describes differences in the population, life expectancy, leading causes of death, disability, obesity rate, annual healthcare costs per Medicare beneficiary, and prescription drug use from 1990 to today, and also describes what can be expected in the future.

\begin{tabular}{|c|c|c|c|}
\hline \multirow[t]{2}{*}{ Parameter Estimate } & \multicolumn{3}{|l|}{ Time } \\
\hline & $\mathrm{NSI}^{\mathrm{a}}$ & Today $^{\mathrm{b}}$ & Future (2030-2040) \\
\hline Life expectancy at age $65[70,103]$ & 17.2 years & 19.2 years & Expected to increase \\
\hline Percent overweight or obese $[7,11,70,103,104]$ & $\begin{array}{l}60.1 \% \text { (both sexes) } \\
64.4 \% \text { (men) } \\
56.9 \% \text { (women) }\end{array}$ & $\begin{array}{l}72.8 \% \text { (both sexes) } \\
66.7 \% \text { (men) } \\
72.2 \% \text { (women) }\end{array}$ & $\begin{array}{l}\text { Some evidence that the obesity } \\
\text { trend is leveling off, but it is still very } \\
\text { high. }\end{array}$ \\
\hline $65-74$ & $\begin{array}{l}64.1 \% \text { (both sexes) } \\
68.5 \% \text { (men) } \\
60.3 \% \text { (women) }\end{array}$ & $\begin{array}{l}77.5 \% \text { (both sexes) } \\
76.9 \% \text { (men) } \\
73.8 \% \text { (women) }\end{array}$ & -- \\
\hline $75+$ & $\begin{array}{l}53.9 \% \text { (both sexes) } \\
56.5 \% \text { (men) } \\
52.3 \% \text { (women) }\end{array}$ & $\begin{array}{l}66.2 \% \text { (both sexes) } \\
70.4 \% \text { (men) } \\
62.4 \% \text { (women) }\end{array}$ & -- \\
\hline Percent obese $[11,70,103,104]$ & $\begin{array}{l}22.2 \% \text { (both sexes) } \\
20.3 \% \text { (men) } \\
23.6 \% \text { (women) }\end{array}$ & $\begin{array}{l}37.8 \% \text { (both sexes) } \\
36.9 \% \text { (men) } \\
38.6 \% \text { (women) }\end{array}$ & $\begin{array}{l}\text { Some evidence that the obesity } \\
\text { trend is leveling off, but it is still very } \\
\text { high. }\end{array}$ \\
\hline $65-74$ & $\begin{array}{l}25.6 \% \text { (both sexes) } \\
24.1 \% \text { (men) } \\
26.9 \% \text { (women) }\end{array}$ & $\begin{array}{l}44.2 \% \text { (both sexes) } \\
42.9 \% \text { (men) } \\
45.4 \% \text { (women) }\end{array}$ & -- \\
\hline $75+$ & $\begin{array}{l}17.0 \% \text { (both sexes) } \\
13.2 \% \text { (men) } \\
19.2 \% \text { (women) }\end{array}$ & $\begin{array}{l}29.0 \% \text { (both sexes) } \\
27.3 \% \text { (men) } \\
30.2 \% \text { (women) }\end{array}$ & -- \\
\hline Prescription drug use $[7,104]$ & $\begin{array}{l}45 \% \text { took }>2 \text { prescription drugs per } \\
\text { day }\end{array}$ & $\begin{array}{l}89.7 \% \text { take at }>1 \text { prescription drug } \\
\text { per day } \\
39.7 \text { percent take }>5 \text { per day }\end{array}$ & $\begin{array}{l}\text { Unlikely to decrease and may } \\
\text { increase }\end{array}$ \\
\hline Average length of stay in hospital (in days) [104] & & & \\
\hline $\begin{array}{l}65-74 \\
75-84\end{array}$ & $\begin{array}{l}8.0 \\
9.1\end{array}$ & $\begin{array}{l}5.4 \\
5.7\end{array}$ & $\begin{array}{l}- \\
--\end{array}$ \\
\hline
\end{tabular}




\begin{tabular}{|c|c|c|c|}
\hline $85+$ & 9.6 & 5.6 & -- \\
\hline Top five causes of mortality [104] & $\begin{array}{l}\text { Heart disease } \\
\text { Cancer } \\
\text { Chronic lower respiratory diseases } \\
\text { Cerebrovascular disease } \\
\text { Influenza and pneumonia }\end{array}$ & $\begin{array}{l}\text { Heart disease } \\
\text { Cancer } \\
\text { Chronic lower respiratory diseases } \\
\text { Cerebrovascular disease } \\
\text { Alzheimer's }\end{array}$ & -- \\
\hline \multicolumn{4}{|l|}{$\begin{array}{l}\text { Proportion of older adults with } 1 \text { or more disabilities } \\
{[70,105]}\end{array}$} \\
\hline $65-74$ & $45 \%$ & $26.2 \%$ & -- \\
\hline $75-84$ & $64 \%$ & $44.9 \%$ & -- \\
\hline $85+$ & $84 \%$ & $72.6 \%$ & $\begin{array}{l}\text { Expected to increase with an } \\
\text { increase in oldest old population }\end{array}$ \\
\hline $\begin{array}{l}\text { Average annual healthcare cost per Medicare } \\
\text { beneficiary [11] }\end{array}$ & $\$ 9850$ & $\$ 15,709$ & -- \\
\hline $65-74$ & $\$ 7330$ & $\$ 11,793$ & -- \\
\hline $75-84$ & $\$ 10,779$ & $\$ 18,160$ & -- \\
\hline $85+$ & $\$ 19,052$ & $\$ 23,693$ & -- \\
\hline \multicolumn{4}{|c|}{ Note. a. Based on statistics collected between 1988-1994 } \\
\hline
\end{tabular}

Table 1: Changes in Characteristics of Older Americans.

\section{Focus on the Oldest Old (Elderly)}

Those older Americans most vulnerable to malnutrition are the oldest old (aged 85 and older), minority group members, women, those with limited income or resources, those isolated from family or friends, those who lack access to adequate diet, and those whose selfcare abilities are limited [12]. With the population of older people steeply on the rise, the number of those in nursing homes decreasing and the known higher risk for malnutrition in the oldest of the older population, home-based nursing and community-based efforts to identify, prevent, and treat malnutrition and its antecedents are a vital part of preventive healthcare and thus are important for the long-term health of the population.

\section{Key Indicators of Elder Well Being}

A recent European Commission project on Active and Healthy Aging suggests that healthy and active aging involves not only maintaining physical, mental, and social well-being, but also continuing contributions to society later in life, including participation in civic, cultural, economic, physically active, social, and spiritual affairs [13]. Nutrition is viewed as important to add healthy life years. In the United States, the federal government periodically issues a report on the overall condition of the US population age 65 and over, summarized in 37 key indicators of critical aspects of older people's lives. Six major areas include: population demographics, economics, health status indicators, health risks and behaviors, health care and end of life issues [11]. Indicators focus on many issues that bear at least a peripheral relationship to nutrition, including diet quality, physical activity, obesity, sensory impairments and oral health, chronic health conditions, depressive symptoms, and functional limitations; but none address nutritional status as a whole or specifically consider rates of malnutrition.

\section{The Nutrition Screening Initiative}

The multidisciplinary NSI is an example of one attempt to make malnutrition screening a vital sign. It was launched in 1990 to identify, prevent, or manage nutritional risks that might otherwise cause disability in older Americans [7,14]. The goal was that attention to nutrition, similar to other vital signs of health, become routine in healthcare. Table 2 provides definitions of key terms used in this article [15]. Risk factors and indicators of potential nutrition problems identified by the NSI are listed in Table 3 [16].

\begin{tabular}{|l|l|}
\hline Phrase & Definition \\
\hline Poor nutritional status & $\begin{array}{l}\text { The presence of classical dietary deficiency diseases, dehydration, undernutrition and nutritional imbalances, as well as obesity, and } \\
\text { alcohol abuse }\end{array}$ \\
\hline $\begin{array}{l}\text { Risk factors of poor nutritional } \\
\text { status }\end{array}$ & $\begin{array}{l}\text { Characteristics associated with an increased likelihood of poor nutritional status, including the presence of acute or chronic diseases } \\
\text { and conditions, inadequate or inappropriate food intake, poverty, dependency/disability, and chronic medication use }\end{array}$ \\
\hline
\end{tabular}


Citation: Watson K, Farrell M, Arensberg MB, Dwyer J (2014) Nutrition as a Vital Sign: Progress Since the 1990 Multidisciplinary Nutrition Screening Initiative and Opportunities for Nursing. J Nurs Care 4: 224. doi:10.4172/2167-1168.1000224

Page 4 of 15

\begin{tabular}{|c|c|}
\hline $\begin{array}{l}\text { Indicators of poor nutritional } \\
\text { status }\end{array}$ & Dietary, clinical, anthropometric biochemical clinical (nutrition related conditions or diseases), and dietary measures \\
\hline Nutrition screening & $\begin{array}{l}\text { The process of identifying characteristics known to be associated with dietary or nutritional problems in order to identify individuals who } \\
\text { are at high risk of nutritional problems or who are already in poor nutritional status }\end{array}$ \\
\hline Nutrition assessment & $\begin{array}{l}\text { Measurement of indicators of dietary or nutrition-related risk that are associated with impaired nutritional status to identify their } \\
\text { presence, nature, and extent, and to obtain the information needed for intervention, planning and improvement through nutritional } \\
\text { measures }\end{array}$ \\
\hline Nutrition intervention & $\begin{array}{l}\text { Action to decrease the risk of or to treat the multifactorial causes of poor nutritional status that may be taken by many different health } \\
\text { and social service professionals as well as family and community members }\end{array}$ \\
\hline Nutrition education & $\begin{array}{l}\text { Imparts information about foods and nutrients, diets, lifestyle factors, community nutrition resources and services to improve nutritional } \\
\text { status }\end{array}$ \\
\hline Nutrition counseling & $\begin{array}{l}\text { Individualized guidance on appropriate food and nutrient intakes for those with special diet related health and social needs, taking into } \\
\text { consideration health, cultural, socioeconomic, functional and psychological factors }\end{array}$ \\
\hline Nutrition support & $\begin{array}{l}\text { Modification of alimentation to improve nutritional status by altering the nutrient content, nutrient density or consistency of usual food } \\
\text { provided or the route of administration }\end{array}$ \\
\hline
\end{tabular}

Table 2: Definitions.

\begin{tabular}{|c|c|c|}
\hline Risk Factors & Major Indicators & Minor Indicators \\
\hline Inappropriate food intake & Weight loss & Alcoholism \\
\hline Poverty & Under-/overweight & Cognitive impairment \\
\hline Social isolation & Low serum albumin & Chronic renal insufficiency \\
\hline Dependency/disability & Change in functional status & Multiple concurrent medications \\
\hline Acute/chronic diseases or conditions & Inappropriate food intake & Malabsorption syndromes \\
\hline Chronic medication use & Mid-arm muscle circumference $<10$ th percentile & Anorexia, nausea, dysphagia \\
\hline \multirow[t]{7}{*}{ Advanced age $(80+)$} & Triceps skinfold $<10$ th percentile or $>95$ th percentile & Change in bowel habit \\
\hline & Obesity & Fatigue, apathy, memory loss \\
\hline & Nutrition-related disorders & Poor oral/dental status, dehydration \\
\hline & -Osteoporosis & Poorly healing wounds \\
\hline & -Osteomalacia & Loss of subcutaneous fat and/or muscle mass \\
\hline & -Folate deficiency & Fluid retention \\
\hline & -B12 deficiency & Reduced iron, ascorbic acid, zinc \\
\hline
\end{tabular}

Table 3: Risk Factors and Indicators for Malnutrition.

In 1990, many of the efforts to improve elderly nutrition centered around home-delivered meal programs and provision of food or inkind resources, such as food stamps, rather than on identifying and preventing the root causes of malnutrition in healthcare and other settings [17]. The NSI was developed as a collaborative effort to help practitioners identify and ameliorate malnutrition in older Americans. Its ultimate goal was to promote more timely interventions in prevention, treatment, and care of malnutrition in noninstitutionalized older adults [18]. The primary organizations leading the NSI were the American Academy of Family Physicians, the American Dietetic Association (now the Academy of Nutrition and Dietetics [AND]), and the National Council on the Aging, with funding provided, in part, by the Ross Products Division of Abbott Laboratories, Inc.

\section{Screening \& assessment}

The NSI developed three basic screening and assessment tools: the "DETERMINE Your Nutritional Health" Checklist, the Level I Screen, and the Level II Screen [16]. The DETERMINE Checklist (Table 4) was intended to provide a public awareness tool an elder could selfadminister or that could be administered by a family member or caregiver. It was also useful as a mnemonic device for providers to check for the "warning signs" of nutritional problems. The Checklist helped practitioners identify older people with low intakes and poor health, but was not validated as a diagnostic data collection instrument [19]. Two other instruments (the Level I and Level II screens-Table 4) focused more on assessment by healthcare professionals, were less widely used, and (to our knowledge) have not been validated. The NSI produced a variety of other checklists including the Oral Health Checklist, Medications Use Checklist, Feeding Difficulties Checklist, and Nutrition Counseling Checklist [12]. 
Citation: Watson K, Farrell M, Arensberg MB, Dwyer J (2014) Nutrition as a Vital Sign: Progress Since the 1990 Multidisciplinary Nutrition Screening Initiative and Opportunities for Nursing. J Nurs Care 4: 224. doi:10.4172/2167-1168.1000224

Page 5 of 15

\begin{tabular}{|c|c|c|c|c|}
\hline Name of Tool & Intended screener & Intended use & Items included & Comments \\
\hline $\begin{array}{l}\text { DETERMINE } \\
\text { Checklist }\end{array}$ & $\begin{array}{l}\text { Self, family member, } \\
\text { or caregiver }\end{array}$ & Awareness and education & $\begin{array}{l}\text { - Disease } \\
\text { - Eating poorly } \\
\text { - Tooth loss/mouth pain } \\
\text { - Economic hardship } \\
\text { - Reduced social contact } \\
\text { - Multiple medicines } \\
\text { - Involuntary weight loss/gain } \\
\text { - Needs assistance in self care } \\
\text { - Elder years above age } 80\end{array}$ & Invalid as a diagnostic tool \\
\hline Level I Screen (LI) & $\begin{array}{l}\text { Health or social } \\
\text { service workers }\end{array}$ & $\begin{array}{l}\text { Singles out older adults in need of } \\
\text { additional nutritional or medical } \\
\text { intervention }\end{array}$ & $\begin{array}{l}\text { - Weight } \\
\text { - BMl } \\
\text { - Eating habits } \\
\text { - Living environment } \\
\text { - Functional status }\end{array}$ & $\begin{array}{l}\text { Ideally, the majority of } \\
\text { information would be collected } \\
\text { during a physical examination } \\
\text { or would be available in the } \\
\text { patient's medical chart. [16] }\end{array}$ \\
\hline Level II Screen (LII) & $\begin{array}{l}\text { Physician or other } \\
\text { health professional }\end{array}$ & $\begin{array}{l}\text { Administered when a patient's } \\
\text { Checklist or Level I Screen denotes } \\
\text { a potential problem, and is intended } \\
\text { to trigger interventions }\end{array}$ & $\begin{array}{l}\text { - Height } \\
\text { - Weight } \\
\text { - BMI } \\
\text { - Triceps skinfold } \\
\text { - Mid-arm muscle circumference } \\
\text { - Serum albumin } \\
\text { - Serum cholesterol } \\
\text { - Medication use } \\
\text { - Clinical findings (including oral problems, } \\
\text { functional eating problems, history of bone } \\
\text { pain or fractures, and skin changes) } \\
\text { - Mental/cognitive status } \\
\text { - Questions from LI Screen (eating habits, } \\
\text { living environment, and functional status) }\end{array}$ & $\begin{array}{l}\text { Upon completion of the Level I } \\
\text { Screen, theoretically, only a few } \\
\text { additional questions are needed } \\
\text { to have a complete Level II } \\
\text { Screen. The mental/cognitive } \\
\text { component was the } 1975 \\
\text { Folstein Mini-Mental State } \\
\text { Examination, the } 1983 \text { Geriatric } \\
\text { Depression Scale (GDS), and } \\
\text { the } 1972 \text { Beck Depression } \\
\text { Inventory-Short Form (BDI). }\end{array}$ \\
\hline
\end{tabular}

Table 4: Nutrition Screening Initiative Tools.

\section{Interventions Recommended by NSI}

The intent of the DETERMINE Your Nutritional Health Checklist and the LI and LII Screens was to link findings to multidisciplinary, clinical care interventions for particular nutrition-related risk factors. The screening and assessment data collection instruments were intended to prompt social service and healthcare providers to intervene with various measures as appropriate. NSI identified multiple intervention categories: social services, oral health, mental health, medication use, nutrition education and counseling, and nutrition support [15]. Interventions included not only conventional medical and nutrition therapy, but broader health and social services targeted to specific nutritional problems.

\section{Progress in the 20 Years since NSI}

Following the NSI, the basic ideas were validated, standardized, implemented, and accepted. The DETERMINE Checklist was validated for educational purposes and for encouraging dialogue among health professionals and older patients. The NSI along with other organizations distributed one million Checklists within the first five years. The Checklist was translated into several languages, and 40 states instituted projects based on NSI's model [12]. The Administration on Aging promoted the material, and federal funds were awarded for research on screening and interventions [12]. Some researchers found that the NSI instruments were particularly helpful for identifying those at risk and guiding educational interventions in a variety of settings [20-22]. The NSI instruments were and still are used nationally, and the DETERMINE Your Nutritional Health Checklist was reportedly used more than any other screening instrument for non-institutionalized, older adults [23]. However, the NSI also faced a number of challenges. Table 5 lists specific challenges at the NSI's initiation, others that still remain, as well as accomplishments over the last 20 years.

\begin{tabular}{|l|l|}
\hline Challenges remaining in 1994 & Challenge addressed in the interim? \\
\hline Lack of validation [106] & New validated tools developed \\
\hline Overestimated/underestimated those at risk and lacked specificity [23,107-112] & New validated tools developed \\
\hline Did not meet criteria for a "screening" instrument [6,113,114] & New screening tools developed \\
\hline Failure to intervene & Remains a problem \\
\hline Failure to integrate interventions and allied health & Remains a problem \\
\hline Lack of medical training in nutrition [115] & Remains a problem \\
\hline
\end{tabular}


Citation: Watson K, Farrell M, Arensberg MB, Dwyer J (2014) Nutrition as a Vital Sign: Progress Since the 1990 Multidisciplinary Nutrition Screening Initiative and Opportunities for Nursing. J Nurs Care 4: 224. doi:10.4172/2167-1168.1000224

Page 6 of 15

\begin{tabular}{|c|c|}
\hline Institutionalization and adoption never documented & Standardization still a problem \\
\hline Transition of care after identification of problem & Remains a problem \\
\hline Failure of healthcare reforms of 1990s [116] & $\begin{array}{l}\text { Opportunity for addition of nutrition in new Medicare } \\
\text { Wellness Visit (Patient Protection and Affordable Care } \\
\text { Act } 2010 \text { ) and opportunity within Older Americans Act } \\
\text { reauthorization }\end{array}$ \\
\hline $\begin{array}{l}\text { Remaining need for research (malnutrition prevalence in older Americans, efficacy of nutrition services, and } \\
\text { cost effectiveness of interventions) [117] }\end{array}$ & Research needs remain \\
\hline The tool depended on a weak infrastructure of social and health services & $\begin{array}{l}\text { As healthcare reform goes into effect, there is an } \\
\text { opportunity for U.S. systems to improve. }\end{array}$ \\
\hline Screening never regarded as a vital sign & Remains a problem \\
\hline
\end{tabular}

Table 5: Challenges Remaining After NSI Initiation, and Challenges Addressed in the Interim.

\section{New Screening Data Collection Instruments}

The NSI's primary purpose was to call attention to a problem and not necessarily to create screening instruments of its own. Since the NSI's initiation in 1990, additional instruments have been developed for screening for malnutrition, many of which have been validated, and nutrition and healthcare professionals have welcomed these developments. The AND provides a comprehensive list of a number of commonly used malnutrition screening instruments [24]. A selection of these instruments is described in Table 6.

\begin{tabular}{|c|c|}
\hline Tool & Summary \\
\hline \multirow[t]{2}{*}{$\begin{array}{l}\text { Council on Nutrition Appetite Questionnaire (CNAQ) and Simplified Nutritional } \\
\text { Appetite Questionnaire (SNAQ) }[24,118,119]\end{array}$} & $\begin{array}{l}\text { CNAQ is based on the Netherlands' Appetite, Hunger, and Sensory Perception } \\
\text { Questionnaire (AHSPQ), and consists of } 8 \text { items. It correlates with the MNA and with } \\
\text { body weight in a non-institutionalized older Dutch population, and was deemed } \\
\text { reliable and valid for assessing appetite in older Americans and identifying those at } \\
\text { risk for significant weight loss. }\end{array}$ \\
\hline & $\begin{array}{l}\text { The SNAQ is a derivative of CNAQ, but includes } 4 \text { questions and has therefore been } \\
\text { regarded as more clinically efficient. It is used in both community-dwelling } \\
\text { populations and long-term care. }\end{array}$ \\
\hline Malnutrition Screening Tool (MST)[24,120-123] & $\begin{array}{l}\text { The MST is based on two questions related to unintentional weight loss and appetite. } \\
\text { It takes } 2-3 \text { minutes and is an effective predictor of risk when compared to Subjective } \\
\text { Global Assessment (SGA). It is sensitive, specific, and in agreement with SGA, and } \\
\text { may prevent hospital-acquired malnutrition as well as identify those at risk in the } \\
\text { residential setting. }\end{array}$ \\
\hline Malnutrition Universal Screening Tool (MUST) $[24,120,124]$ & $\begin{array}{l}\text { The MUST uses three criteria: weight, height, BMl; unintentional weight loss; and } \\
\text { acute disease affecting intake to determine nutritional risk. The tool is updated } \\
\text { annually and takes } 2-3 \text { minutes to complete. It has been validated for nutrition } \\
\text { assessment in long-term care. }\end{array}$ \\
\hline $\begin{array}{l}\text { Mini Nutrition Assessment (MNA) and Mini Nutrition Assessment-Short Form } \\
\text { (MNA-SF) }[24,125]\end{array}$ & $\begin{array}{l}\text { The MNA was developed by Nestle Nutrition and can effectively identify older adults } \\
\text { at risk for malnutrition. The } 4 \text { anthropometric measures and } 15 \text { questions, of the } \\
\text { MNA must be administered by a professional, while the MNA-SF includes } 6 \\
\text { questions and can be administered much more quickly and without prior training. The } \\
\text { MNA has been validated by more than } 450 \text { studies, and is reportedly the most } \\
\text { validated tool for older people. Its scoring system is linked to a decision tree to } \\
\text { determine appropriate interventions. }\end{array}$ \\
\hline SCALES $[24,126]$ & $\begin{array}{l}\text { SCALES is particularly useful in long-term care. This tool uses cholesterol, albumin, } \\
\text { sadness, weight loss, and eating problems to assess risk. Non-medical professionals } \\
\text { can use it because it does not require a sophisticated physical exam. }\end{array}$ \\
\hline $\begin{array}{l}\text { Seniors in the Community Risk Evaluation for Eating and Nutrition (SCREEN II) } \\
{[24,127-130]}\end{array}$ & $\begin{array}{l}\text { SCREEN II, an improved version of the original SCREEN I, identifies community- } \\
\text { living older adults at risk for impaired nutrition status. This is the only tool to have } \\
\text { undergone structural equation modeling and confirmatory factor analysis, and it has } \\
\text { demonstrated high validity. Health professionals are increasingly using SCREEN II in } \\
\text { Canada, though the tool is preferably self-administered. }\end{array}$ \\
\hline
\end{tabular}

Table 6: New Screening Instruments.

Nurses can work with dietitians to help select the appropriate malnutrition screening data collection instrument, as the task can be overwhelming; 71 instruments were recently identified--21 of them targeted to older adults [25]. Several commonly used instruments, 
(among others not described in detail in this paper) include the Nutrition Risk Screen (NRS-2002), the Instant Nutritional Assessment (INA), the Patient-Generated Subjective Global Assessment (PGSGA), the Nutrition Screening Tool (NST), the Birmingham Nutrition Risk (BNR) Score, and the Australian Nutritional Screening Initiative (ANSI). While a number of instruments exist, it is important that a selection is made carefully, as many lack validation and may not be specific or sensitive enough for clinical use [25]. We suggest using any of the following, validated, screening tools: the Mini-Nutritional Assessment-Short Form (MNA-SF), the Malnutrition Screening Tool (MST), the Malnutrition Universal Screening Tool (MUST), and the SCREEN-II. Most are available for public use. We suggest the DETERMINE Checklist for educational purposes (Figure 1). These simple questions, coupled with astute physical assessment of the older person, lay a foundation upon which a more elaborate structure can later be developed.

\begin{tabular}{|c|c|c|c|}
\hline \multicolumn{4}{|c|}{$\begin{array}{l}\text { The warning signs of poor nutritional } \\
\text { health are often overlooked. Use this } \\
\text { checklist to find out if you or someone you } \\
\text { know is at nutritional risk. } \\
\text { Read the statements below. Circle the number in the } \\
\text { yes column for those that apply to you or someone } \\
\text { you know. For each yes answer, score the number in } \\
\text { the box. Total your nutritional score. }\end{array}$} \\
\hline & Yes \\
\hline \multicolumn{3}{|c|}{ I have an illness or condition that made me change the kind and/or amount of food I eat. } & 2 \\
\hline \multicolumn{3}{|c|}{ I eat fewer than 2 meals per day. } & 3 \\
\hline \multicolumn{3}{|c|}{ I eat few fruits or vegetables or milk products. } & 2 \\
\hline \multicolumn{3}{|c|}{ I have 3 or more drinks of beer, liquor, or wine almost every day. } & 2 \\
\hline \multicolumn{3}{|c|}{ I have tooth or mouth problems that makes it hard for me to eat. } & 2 \\
\hline \multicolumn{3}{|c|}{ I don't always have enough money to buy the food I need. } & 4 \\
\hline \multicolumn{3}{|c|}{ I eat alone most of the time. } & 1 \\
\hline \multicolumn{3}{|c|}{ I take 3 or more different prescribed or over-the-counter drugs a day. } & 1 \\
\hline \multicolumn{3}{|c|}{ Without wanting to, I have lost or gained 10 pounds in the last 6 months. } & 2 \\
\hline \multicolumn{3}{|c|}{ I am not always physically able to shop, cook, and/or feed myself. } & 2 \\
\hline & & TOTAL & \\
\hline \multicolumn{2}{|c|}{ Total Your Nutritional Score. If it's- } & \multirow{2}{*}{\multicolumn{2}{|c|}{$\begin{array}{l}\text { These materials developed and } \\
\text { distributed by the Nutrition Screening } \\
\text { Initiative, a project of: }\end{array}$}} \\
\hline $0-2$ & $\begin{array}{l}\text { Good! Recheck your nutritional score in } 6 \\
\text { months. }\end{array}$ & & \\
\hline \multirow[t]{3}{*}{$3-5$} & \multirow{3}{*}{$\begin{array}{l}\text { You are at moderate nutritional risk. } \\
\text { See what can be done to improve your eating } \\
\text { habits and lifestyle. Your office on aging. senior } \\
\text { nutrition program, senior citizens center, or } \\
\text { health department can help. Recheck your } \\
\text { nutritional score in } 3 \text { months. }\end{array}$} & \multicolumn{2}{|l|}{$\begin{array}{l}\text { American Academy } \\
\text { of Family Physicians }\end{array}$} \\
\hline & & \multicolumn{2}{|l|}{$\begin{array}{l}\text { The American } \\
\text { Dietetic Association }\end{array}$} \\
\hline & & \multicolumn{2}{|l|}{$\begin{array}{l}\text { National Council } \\
\text { on the Aging }\end{array}$} \\
\hline 6 or more & $\begin{array}{l}\text { You are at high nutritional risk. Bring } \\
\text { this checklist the next time you see your doctor. } \\
\text { dietitian or other qualified health or social } \\
\text { service professional. Talk with him or her about } \\
\text { any problems you may have. Ask for help to } \\
\text { improve your nutritional health. }\end{array}$ & \multicolumn{2}{|c|}{$\begin{array}{l}\text { Remember that warning signs } \\
\text { suggest risk, but do not represent } \\
\text { diagnosis of any condition. Continue } \\
\text { reading to learn more about the warning } \\
\text { signs of poor nutritional health. }\end{array}$} \\
\hline
\end{tabular}

Figure 1: DETERMINE Checklist [131].

\section{Other Metrics than NSI for Assessing Risk and Frameworks for Intervention}

\section{Frailty Index}

Frailty is often thought of as a risk factor for both disability and mortality, but others regard it as a clinical syndrome with a biological basis [26]. Fried developed a frailty index that identifies the frail based on a set of five factors: unintentional weight loss, self-reported exhaustion, weakness, slow walking speed, and low physical activity. Individuals with three or more of these factors are considered frail.
Those with one or two factors are termed "intermediate frail" or "prefrail" [26]. Frailty is considered predictive of worsened mobility, low ADLs, disability, hospitalization, and mortality [26]. A group of international experts has agreed on these characteristics of physical frailty:[27]

- Frailty is "a medical syndrome with multiple causes and contributors that is characterized by diminished strength, endurance, and reduced physiologic function that increases an individual's vulnerability for developing increased dependency and/or death" [27].

- Potentially it can be prevented or treated with specific modalities, such as physical activity, protein-calorie supplementation, vitamin D supplementation, and polypharmacy reduction.

- Simple, validated screening tests (e.g. the Simple FRAIL Questionnaire) are available and allow physicians to recognize frail persons.

- Anyone older than 70 years and anyone presenting with significant weight loss $(\geq 5 \%)$ secondary to chronic disease should be screened.

The frailty index and Simple FRAIL Questionnaire (Table 7), if standardized and adopted, may prove to be useful as another indicator for malnutrition risk. It is important to identify pre-frail and frail individuals, prevent disability, and implement interventions to manage frailty in clinical practice. This is particularly so since frailty is a clinical syndrome that develops as a consequence of age-related decline in many physiological systems and increases an individual's vulnerability for developing further dependency and even mortality when exposed to one or more stressors. Recently, a FRAILTY.NET website (http://www.frailty.net) has been established to document current developments.

\section{3 or greater $=$ Frailty \\ $1-2=$ Prefrail}

Fatigue: Are you fatigued?

Resistance: Cannot walk up 1 flight of stairs?

Aerobic: Cannot walk 1 block?

Illnesses: Do you have more than 5 illnesses?

Loss of weight: Have you lost more than $5 \%$ of your weight in the past 6 months?

Table 7: Simple FRAIL Questionnaire Screening Tool [27].

\section{Intervention frameworks}

In addition to selecting a screening data collection instrument for malnutrition, it is also critical for nurses to work with dietitians to help build the framework and integrate the patient care processes to ensure timely and appropriate malnutrition interventions. Recently, the Alliance to Advance Patient Nutrition (The Alliance) published a consensus paper showcasing a model for an interdisciplinary approach to addressing malnutrition in hospitals and during the post-acute phase. The Alliance is a collaboration of the Society for Hospital Medicine, the AND, the Academy of Medical Surgical Nurses, and Abbott Nutrition. While its approach is focused on malnutrition in hospitalized patients in general, many of the examples are specific to older adults. The consensus paper summarized several, validated malnutrition screening instruments for hospitalized patients and 
emphasized that the key to improving nutrition is to "systematically identify patients who are malnourished, or at risk, and to promptly intervene." The novel care model they developed to drive improvement emphasized six multidisciplinary actions, and in each, nursing has a role [28]:

- Create an institutional culture where all stakeholders value nutrition;

- Redefine clinicians' roles to include nutrition care;

- Recognize and diagnose all malnourished patients and those at risk;

- Rapidly implement comprehensive nutrition interventions and continued monitoring;

- Communicate nutrition care plans to all healthcare professionals; and,

- Develop a comprehensive discharge nutrition care and education plan.

\section{Documenting Impact and Value of Nutrition Intervention}

The consensus paper from the Alliance to Advance Patient Nutrition also provided evidence of the impact of malnutrition interventions on health outcomes. The paper documented "numerous studies, predominantly in patients 65 years of age and older, with or at risk for malnutrition, have shown the potential of specific nutrition interventions to substantially reduce complications, length of hospital stay, readmission rates, cost of care, and in some studies, mortality" [28].

Translating such evidence into value is important. It was recently noted that under healthcare payment reform, the shifting focus toward greater health care provider accountability for costs and quality will expand providers' roles from just delivering treatment and care to both delivering and prioritizing care based on quality and costs [29].Use of oral nutrition supplements for hospitalized patients was identified as one example of low cost, high value services that have typically not been reimbursed, but have evidence of value and represent an opportunity to improve quality and decrease costs. Further evidence of the economic value of oral nutrition supplements for hospitalized older adults is documented in a recent study using a Premier Perspectives Database of Medicare patients over an 11-year period. The study's results showed a decreased probability for 30-day readmission, length of stay, and episode cost for patients using oral nutrition supplements such as Ensure ${ }^{\oplus}$ or Boost $^{\oplus}$ [30].

\section{Next Steps: Challenges Remaining Today and Areas of Opportunity}

The demographics of today's older adult population and the evolution of malnutrition screening and intervention instruments and practices provide an opportune environment for nursing to help malnutrition screening become a vital sign. The next steps for this to occur are outlined below and include: prioritizing malnutrition screening and intervention within healthcare and community-based organizations and education programs, evolving standards for malnutrition measurement and documentation, developing national malnutrition goals, integrating malnutrition screening and intervention into healthcare models and incentives, committing funding for malnutrition screening and intervention, and learning from international experiences. Nurses are often the clinicians most active in developing vital signs and their leadership in collaboration with dietitians and other healthcare professionals is essential to success in ensuring that malnutrition screening becomes a vital sign for older adults. Nurses, especially those who conduct home visits, interact with caretakers of elderly family members, or serve as consultants to longterm care facilities, could join with dietitians to initiate the process.

\section{Prioritizing Malnutrition Screening and Intervention within Healthcare and Community-based Organizations and Education Programs}

Making malnutrition screening and intervention priorities starts with nutrition professionals. A recent survey examined the major public policy alignment areas of five, American, nutrition professional societies: the AND, the American Society of Nutrition (ASN), the American Public Health Association (APHA), the American Society for Parenteral and Enteral Nutrition (ASPEN), and the Society for Nutrition Education and Behavior (SNEB). Of the five, none of the organizations explicitly focused on malnutrition screening as a priority area [31]. More attention needs to be called to the issue of malnutrition screening in order for powerful organizations like these to effectively influence US policy.

Malnutrition screening and intervention also need to be part of the core curriculum and training for other healthcare professionals because there simply are not enough dietitians to identify and treat all the patients at risk for malnutrition. A lack of sufficient nutrition education in medical schools existed at NSI's implementation and is still a challenge. Nurses, nurse practitioners, and physician assistants represent a critical reserve that could be tapped for screening and interventions involving nutrition and the elderly. Their education and training in nutrition is essential, yet needs to be strengthened. In some nursing programs, nutrition has been eliminated as a separate course and is considered as a strand across and through theory and clinical nursing courses. However, this practice ignores the reality that not all faculty are knowledgeable enough to carry out this mandate in a comprehensive way. Other baccalaureate nursing programs require nutrition education as a separate course, and also incorporate nutrition into their clinical nursing courses [32]. Nutrition content is a testable category on registered nurse licensure examinations [33]. However, there is no mandate that formally requires inclusion of nutrition in nursing education at the baccalaureate or the graduate level [34,35]. The Essentials of Baccalaureate Education for Professional Nursing Practice includes mention of nutrition as part of the "sample content" for education programs, but not as part of the essential curricular elements or outcomes that delineate the knowledge, skills, and attitudes of new graduates [34]. Even when considering the specific competency and curricular recommendations for the nursing care of older adults, nutrition still has limited mention and is considered part of the "support courses" rather than a core component of education. Nutrition is not reflected as a recommended competency for gerontological nursing and that has not changed since publication of the previous recommendations over 10 years ago [36,37].

Knowledge of nutrition is vital to the nurse, as he or she is frequently responsible for lifestyle counseling, malnutrition screening, and health promotion, in addition to palliative and curative care [38]. Unfortunately, nutrition curricula education in nursing schools have not been examined since the early 1990's and that information is now outdated [39-41]. Formal evaluations of nutrition education methods in nursing schools are also dated [42].When considering the nutrition continuing education needs of practicing nurses, the literature is equally limited and the papers reflect only international nursing 
practice [43-45]. A survey is warranted to determine the status of nursing nutrition education today, both for students and practitioners, and to fill existing gaps [38].

Yeung et al. conducted an ethnographic study of vital signs collection and documentation of 24 nurses' practices in a general internal medicine environment. They noted the lack of standardized documentation methods regarding vital signs that lead to higher rates of transcription, enhancing the possibility of errors and delays in the recording and use of information. They indicated that the system was not conducive to documentation at the point of care. Overall, the average time to electronically document was significantly longer than documentation on paper, and respondents found ways to work around the processes that were characterized as being inefficient [46].

A specific focus on older adults and involvement from a broader range of organizations is required to influence nursing education and change clinical practice. And, as both the US and other countries are experiencing a significant nursing shortage that is expected to continue well into the future [47], it is important to consider how other health workers and personal care aides can play a greater role in malnutrition screening and intervention. In addition, new approaches are needed for education and policy mandates like the recent mandate for interprofessional education [32].

\section{Evolving Standards for Malnutrition Measurement and Documentation}

\section{Joint Commission Standards}

For malnutrition screening to become a vital sign, malnutrition must be regularly measured and documented. For nursing, a summative measure would be useful and could be included as part of the standardized nursing language (SNL) with a specific entry section in the electronic health record (EHR). At the time of the NSI, the Joint Commission on Accreditation of Healthcare Organizations (JCAHO) already required malnutrition assessment and monitoring activities in hospitals, and any institution adhering to JCAHO had to adhere to nutrition screening standards [14]. Although the Joint Commission (now abbreviated as TJC) still requires that all patients be screened within 24 hours of admission to a healthcare facility, the screening criteria can vary widely from one facility to the next, and adherence is also variable $[48,49]$. Moreover, interventions are often lacking, with many patients being discharged before a dietitian can assess patients identified at malnutrition risk and intervene. It is important that TJC build into its standard specific malnutrition screening measures and outcome indicators, such as rates of readmissions or hospital-acquired conditions. Such measures need to be multidisciplinary in scope. In this regard, the AND and Avalere recently brought together a number of disciplines, including nursing, and held a dialogue on measuring the quality of malnutrition care in the hospitalized elderly patient. The aim of this dialogue was to identify and prioritize specific focus areas to improve measures of the quality of malnutrition care [50].

\section{Electronic health records}

When considering documentation of malnutrition, an electronic platform is needed as America has increasingly shifted toward EHRs and away from paper records. Specifically, the passage of the American Recovery and Reinvestment Act created an environment that requires the adoption of EHRs by 2014 for 70 percent of the primary care provider population [51]. The EHR systems' nutrition component needs substantial improvement [52]. One instrument that has been suggested for addition to the EHR is the computerized decisionsupport service (CDSS), designed for facilitating end users' (nurses at the bedside and other direct care providers) decisions. It also allows for relevant information and decision-making at the point of care [53]. Researchers have demonstrated the usefulness of a CDSS based on the Mini Nutritional Assessment and the Risk Assessment Pressure Scale in nursing care for prevention of malnutrition and pressure ulcers [54].

With all areas of healthcare moving toward EHRs, clinicians, including dietitians and nurses, need to be involved in early system planning to ensure nutrition components are included [55]. If malnutrition screening and intervention are not added to the basic framework for EHRs, they will have limited visibility among the broader patient care team and will not become a vital sign or part of routine care.

Nurses are also now expected to use the EHR. This technology brings positive quality controls to the process of documentation, but it also presents challenges. For example, Conrad et al. surveyed a randomized sample of 1,997 ambulatory care members of the American Academy of Nurse Practitioners. The researchers found that the value nurse practitioners personally placed on factors influenced their entries into the EHR. These related to reimbursement, the relatively high value placed on medical treatment versus nursing care, the lack of time, and availability of standardized nursing language (SNL) in the EHRs [56].

\section{Developing National Malnutrition Goals}

Becoming part of national health goals is another important step for the evolution of malnutrition screening as a vital sign. Over a decade ago, the only objective in Healthy People 2000 directly addressing nutrition in older adults was related to home-delivered meals [57]. However, the publication did address other areas that could have been linked to nutrition, including the number of older adults who were institutionalized, who had functional limitations, and who had sedentary lifestyles. The attention given to nutrition for older adults in Healthy People 2020 speaks to the progress of nutrition advocacy in America. "Older Adults" is a new topic in and of itself within the Healthy People 2020 agenda, and it now houses 12 objectives related to elderly health [58]. Table 8 describes the objectives of the Healthy People 2020 agenda that potentially relate to the nutrition status of older Americans. More can certainly be done to promote the ways in which malnutrition screening and intervention among elders can impact progress toward achieving these objectives. In addition, it is appropriate for nutrition and nursing professionals to advocate for new health objectives specifically related to malnutrition screening and intervention for elders. 


\begin{tabular}{|l|l|l|}
\hline Objective & Target & Progress \\
\hline $\begin{array}{l}\text { Increase the proportion of adults who use the } \\
\text { Welcome to Medicare Benefit by10\% }\end{array}$ & $7.0 \%$ & $\begin{array}{l}2008: 6.4 \% \\
2010: 8.9 \%\end{array}$ \\
\hline $\begin{array}{l}\text { Increase the proportion of older adults who receive } \\
\text { Diabetes Self-Management Benefits by 10\% }\end{array}$ & $2.2 \%$ & $\begin{array}{l}2008: 2.0 \% \\
2010: 1.8 \%\end{array}$ \\
\hline $\begin{array}{l}\text { Increase the proportion of older adults with reduced } \\
\text { physical or cognitive function who engage in light, } \\
\text { moderate, or vigorous leisure-time physical activities } \\
\text { by 10\% }\end{array}$ & $35.9 \%$ & $2008: 32.6 \%$ \\
\hline $\begin{array}{l}\text { Increase the proportion of dietitians with geriatric } \\
\text { certification by 10\% }\end{array}$ & $0.33 \%$ of RDs & $2012: 39.2 \%$ \\
\hline $\begin{array}{l}\text { Reduce the rate of pressure ulcer-related } \\
\text { hospitalizations among older adults by 10\% }\end{array}$ & 887.3 hospitalizations per 100,000 persons & $2009: 0.30 \%$ \\
\hline
\end{tabular}

Table 8: Healthy People 2020 Goals Related to Elder Nutrition [58].

\section{Integrating Malnutrition Screening and Intervention into Healthcare Models and Incentives}

\section{Patient Protection and Affordable Care Act}

Healthcare reforms provide opportunities to integrate malnutrition screening and intervention into emerging healthcare models and incentives, which can help strengthen their position as a vital sign. Section 4103 of the Patient Protection and Affordable Care Act (ACA) of 2010, "The Medicare Coverage of Annual Wellness Visit Providing a Personalized Prevention Plan," includes a provision for an Annual Wellness Visit (AWV) at no cost to Medicare beneficiaries [59]. This AWV includes a Health Risk Assessment (HRA), and, within 12 months of Medicare enrollment, beneficiaries also receive the "Welcome to Medicare" preventive visit, which is a comprehensive health assessment [60]. CMS published a final ruling in 2012 that made the HRA a requirement, and though there is no mandated format for the HRA, the Centers for Disease Control (CDC) published a framework for the HRA with follow-up activities, and monitoring $[60,61]$. Section 4014 of the ACA authorizes adult preventive services that are graded A or B for no cost sharing (i.e. copayments, deductibles, or co-insurance). The US Preventive Services Task Force (USPSTF) grades these preventive services and makes recommendations for filling gaps and addressing priority areas within the ACA [60]. No malnutrition screening services have been graded A or $\mathrm{B}$, and in its most recent report to Congress, the USPSTF did not include malnutrition screening or intervention in its recommendations $[62,63]$. There is certainly an opportunity for nutrition, nursing, and other healthcare professionals to advocate for this to change.

Although malnutrition screening is not specifically detailed in the HRA, the HRA's preventive focus does include items consistent with typical malnutrition screening tools. For example, an HRA form provided by the CDC includes questions about food frequency, dentition, ADLs and IADLS, mental health, alcohol and tobacco use, physical activity, and self-reported blood pressure, cholesterol, glucose, height, and weight. A number of organizations are also developing new HRA tools, including web-based programs, compliant with the ACA requirements [61]. While most instruments include components of malnutrition screening, dietitians, nurses, and other healthcare professionals should push policymakers for a formal, standard set of malnutrition screening questions to be included in the HRA.

For older Medicare patients who are hospitalized, 19.6 percent are readmitted within 30 days [64]. Readmissions are not always directly related to the primary hospitalizing event, and readmission can sometimes be attributed to "post-hospital syndrome," a condition characterized by heightened vulnerability to infection due to an overall compromised health condition secondary to both their acute illness and the stress induced by hospitalization (poor nourishment, disrupted sleep, pain discomfort, and inactivity) [65]. Nutritionrelated issues like weight loss and decreased serum albumin have been found to be predictors of non-elective readmission within 30 days [66].

Not only is readmission detrimental to the patient, but it also has financial repercussions for hospitals. CMS is now financially penalizing hospitals that fail to meet certain targets in specific areas, such as rates of 30-day readmissions and hospital-acquired conditions $[10,67]$. Conversely, improvements in these measures provide financial rewards for health facilities [67]. Hospital malnutrition is a costly and often overlooked condition [67]. Nurses working in quality-focused areas should see improved patient outcomes and cost reductions as malnutrition screening and intervention are incorporated as a vital part of healthcare. A great need exists for policies to promote better nutrition care before, during, and after hospitalization [67]. In addition to policies, educational programs for nurses at the bedside are essential, as patients' food choices and their subsequent ability to consume the food selected are focal points for malnutrition intervention. Both issues-outcomes for patients and financial penalties or rewards for hospitals-highlight the value of malnutrition screening and intervention in the hospital setting and beyond.

\section{Transitions of Care}

In the same way that transitioning of care from one setting to another was a challenge to the NSI in the 1990s, it remains a challenge today. Without standardized malnutrition screening, a consistent link does not connect hospitals to nursing homes, to home and community care settings, to patients and families. This issue should be approached in a multisystem, not just multidisciplinary way as policymakers, health systems, and healthcare professionals all play a role. The 
Congressional Black Caucus Institute recognized this issue in their most recent 21st Century Council report, where it identified the need to establish nutrition as a routine standard of healthcare. Specifically, the first area listed was "integrating malnutrition screening and treatment into the development of evidence-based care models, such as intervention strategies to improve patient care transitions" [68]. CMS is working to identify and promote best practices through its community-based care transitions program. While some state models include a nutrition component, it is often limited and does not include malnutrition screening. Similarly, White et al. note that, while there are a variety of models developed to enhance post-acute outcomes, no models specifically address identification and treatment of malnutrition post-hospitalization [69].

\section{Community Interventions}

Assisted living facilities and personal care homes need to adopt malnutrition screening and intervention protocols, given the increase in the number of older people in these facilities [70]. Furthermore, as there is often a large gap in care between institutions and primary care, there is also an opportunity for standardized malnutrition screening and intervention as part of the patient-centered medical home (PCMH) model. In this model, the physician communicates directly with patients and leads a team to integrate care across providers [71]. This model has been identified as a new practice and reimbursement opportunity for nurses [72]. The AND, and its state affiliates, are also advocating for dietitians "to be an integral part of the team that provides patient-centered care” [73,74].

In addition, building community awareness of the malnutrition problem is essential. A recent study on a random sample of "cognitively intact, non-critically, ill older adults" in an emergency department found that over half were malnourished or at risk for malnutrition, and the majority of the malnourished patients had not been previously diagnosed with the condition. The researchers concluded that the growing role of emergency departments as sites of care and entry point makes them essential places for identifying and addressing unmet needs such as malnutrition for older adults [75]. In this regard, a simple "vital sign" for malnutrition screening would facilitate the nurse's work.

ASPEN has launched a Malnutrition Awareness Week to raise healthcare professional and community awareness and urge the public to ask about their nutritional status [76].This type of campaign from the non-profit sector needs to be taken up by the CDC and promoted through state departments of health. The CDC's falls prevention campaign might serve as a model. The CDC campaign suggests that "while falls are a threat to the health and independence of older adults and can significantly limit their ability to remain self-sufficient, the opportunity to reduce falls among older adults has never been better. Today, there are proven interventions that can reduce falls and help older adults live better, and longer" [77]. Certainly each of these same statements could be made about malnutrition, and indeed malnutrition has been documented as a risk factor for falls in hospitalized patients [78]. Practice breakdown for malnutrition is as much a concern for nursing as are falls in the elderly.

\section{Committing Funding}

Committing funding for malnutrition screening is important to establishing it as a vital sign. The Older Americans Act (OAA), originally passed in 1965, serves as the granting authority for community, social service, and nutrition programs for elders. It is considered the major vehicle for delivering nutrition services to older Americans and their caregivers [79]. It was last reauthorized in 2006, with an emphasis on embedding consumer information principles in long-term care planning, evidence-based prevention, and self-directed community services for those at risk of institutionalization [80].

The five-year authorization expired in 2011, and the OAA is long past due for reauthorization. The 2014 Older Americans Reauthorization Act calls for improved ability to participate in services and programs in the community for the benefit of older adults [81]. Some of the areas targeted for change include adding "parent caregiver" to the National Family Caregiver Support Program, consolidating funding for community nutrition programs, costsharing for more Title III services, and allowing states to provide prevention and health promotion services only for evidence-based services [82].

The aging population is growing, and yet OAA funding has not kept pace [83-85]. Further, inflation-adjusted funding specifically appropriated for OAA nutrition services has decreased substantially over the past two decades. [86]. This can place elders at risk. A US Government Accountability Office report on OAA from 2011 documented that many older adults with low incomes who were likely to need meals were not receiving them [87]. And some nursing groups, such as the National Black Nurses Association (NBNA), have passed resolutions calling for more focus on nutrition in the OAA. NBNA's resolution specifically supported "the increased emphasis on nutrition for healthy aging through new provisions in the Older Americans Act, including promoting routine nutrition screening for OAA meal program participants and addressing their unique nutritional needs with nutrition interventions that are culturally and age sensitive" [88].

\section{Learning from International Experiences}

In considering pathways to develop malnutrition screening as a vital sign, it is useful to look internationally. Several countries, including the UK, Canada, New Zealand, and Australia, have more advanced tools and policies to integrate malnutrition screening and intervention into routine medical care than does the US. The UK estimates that improving a system of malnutrition screening, assessment, and intervention saved $£ 28,472$ (\$44,514) per 100,000 people [89]. The British Dietetic Association (BDA) recommends embedding screening by using a validated tool like MUST, which facilitates rapid intervention. It encourages a wide range of professionals in helping to identify and treat those at risk of malnutrition [89]. The BDA also recommends that systems in the community and in care settings be in place to identify those at risk of poor nutrition status [90]. A complex new structure of healthcare and social services makes nutrition issues a challenge in the UK today with a call for early intervention in the community setting [90]. With a national estimated cost of $£ 13$ billion ( $\$ 21.5$ billion) associated with malnutrition annually, this organization encourages funding for preventing malnutrition, as well as for intervening and monitoring [90].

The UK held an annual Nutrition Screening Week (NSW) during years 2007-2011 to collect data on malnutrition in each of the four seasons. This initiative helped to raise awareness of the need for malnutrition screening in policy [91]. It found that MUST was the most commonly used tool in the UK and the Republic of Ireland for malnutrition screening in all settings [92]. The NSW also found that, although interventions were linked to screening in inpatient facilities, they were rarely followed up in discharge planning [92]. This 
highlighted a need for stronger transition of care and intervention models.

In Canada, considerable work has been done surrounding the development and validation of the SCREEN II tool. However, an identified barrier in Canadian screening is that nutrition promotion does not hold a prominent place in national policy [93]. Additionally, the prevalence of malnutrition is unknown in Canadian older adults [94].

New Zealand's dietetic association, Dietitians NZ, recommends the use of a valid tool such as MNA, MNA-SF, or MUST, as the acceptable tools for screening older adults in residential care. New Zealand estimates that 7,400 to 19,900 older adults in residential care may be at nutritional risk. This association recommends that malnutrition screening be mandatory on admission, and recommends policies to initiate interventions for residents at risk [95]. In New Zealand, it is considered unethical, however, to screen when there are inadequate resources (such as staffing, equipment, or funding) to lessen an existing problem like malnutrition, once it has been detected [96].

In Australia, the Dietitians Association of Australia (DAA) recommends using the MNA-SF for screening for malnutrition in older people with pressure ulcers. It also recommends that routine malnutrition screening occur in acute care, rehabilitation, residential care, and the community [97]. Valid screening tools recommended by the DAA for acute care include the MST, MUST, MNA-SF, NRS-2002, and SNAQ. For rehabilitation, MNA-SF and Rapid Screen are recommended. In residential care for older adults, the DAA recommends MNA-SF, MUST, SNAQ, and the Simple Nutrition Screening Tool. Finally, in the community setting, MNA-SF, MUST, SCREEN II, SNAQ, and SNAQ(c) are recommended [97]. The DAA offers evidence-based suggestions for interventions following screening, and Dietitians NZ endorses DAA evidence-based guidelines [96]. Similar to new US policy, Australian Medicare provides a health assessment for those 75 years and older, but malnutrition assessment is not required and is dependent on the provider's decision [98].

The global feedM.E. (Medical Education) Global Study Group defines a nutrition care pathway that can be varied depending on the healthcare setting. The Pathway's primary strategies are screen, intervene, and supervene: screen patients' nutrition status on admission or initiation of care, intervene promptly when needed, and supervene or follow up routinely with adjustment and reinforcement of nutrition care plans [99].

A study on over 21,000 patients in Europe and Israel found that, in hospitalized patients, malnutrition screening was most frequently performed using data collection instruments developed locally, rather than using standardized, nationally developed instruments [100]. Yet there is a great need for more uniformity so that comparisons can be made using national standardized instruments across settings, locales, and countries.

\section{Conclusion}

In a remarkably prescient article 30 years ago, a former director of the National Center for Health Statistics and an eminent nurse educator called for a dramatic shift in thinking about policies for restructuring in health and social structures to deal with the growing population of older Americans. Instead of focusing solely on decreasing costs, the director urged that fundamental policy issues needed to be addressed, including health and medical care needs versus supply, alternatives to institutionalization, alternative healthcare delivery systems, financing of long-term care services, and the role of informal support systems, housing, and income maintenance [101]. Instead, policymakers continue to focus on cost cutting and caps on federal spending, which will likely force deep cuts in Medicare, Medicaid, and eventually Social Security, making a majority of older Americans economically vulnerable (e.g., at an income that is less than twice the supplemental poverty threshold) [102-131]. It is often said that prevention is a statistical concept whereas treatment is more tangible. It is far easier to neglect prevention. Yet even a few older Americans with preventable nutrition related problems represent a major human, as well an economic cost; and estimates suggest that many older adults are at risk for malnutrition. Even if current systems for identifying malnourished older adults were $99 \%$ effective, translated into airline travel, that would represent one major airline crash every three days, and at least 84 unsafe landings per day, which most Americans would find unacceptable. We are far from such efficiency at present in identifying preventable malnutrition in the elderly, and much remains to be done.

As was the consensus at the outset of the NSI, "older Americans are their own best allies" [7]. It is often the individual or family in the community who is best able to assess risk for malnutrition. However, healthcare professionals, health systems, and policymakers have a responsibility, too. Systematic malnutrition screening and appropriate interventions for older adults are not standard practice and are still needed. If the nutrition focus of healthcare today remains exclusively on obesity, the malnutrition problem in the elderly will continue to have a significant impact on health outcomes. Other countries seem to be doing a better job than the US of avoiding needless primary and secondary nutrition problems in elders. However, as healthcare reform moves forward, an opportunity arises for US systems to improve. Nutrition and nursing professionals play critical roles in making this happen. The UK held its Nutrition Screening Week for four consecutive years to evaluate malnutrition risk in hospitals and care homes in each season [91]. The ASPEN Malnutrition Week and Alliance to Advance Patient Nutrition models can help build similar momentum in the US to drive policy change. The ingredient needed for success is engagement by the broader healthcare establishment. Today's focus on preventive care, patient involvement, and health outcomes provides the opportune environment to take the evidence of health risks for malnutrition and show real value in making malnutrition screening a true vital sign for older Americans.

\section{Sources of Support}

This work was supported in part by the US Department of Agriculture Cooperative State Research, Education and Extension Service grant \#2006-35200-17259 and the US Department of Agriculture, Agricultural Research Service, under agreement \#589-1950-7-707. Any opinions, findings, conclusions or recommendations expressed here are those of the authors and do not necessarily reflect the view of the US Department of Agriculture.

\section{References}

1. Dwyer J (1993) A vital sign: progress and prospects in nutrition screening of older Americans. Aging (Milano) 5: 13-21.

2. Levin RM (2000) The 7th vital sign: Implementing a malnutrition screening tool at a community cancer center. Onc Nutr Conn. 10-14.

3. Daly C, Grieshop C, Levin R (2012) The 7th vital sign: The role of nutrition in oncology nursing. Nurs Currents. 1. 
4. Holst M, Laursen B, Rasmussen H (2012) Caring for dinner in hospital better organization may improve quality of care around meal serving in a hospital unit. J Nurs Care. 1:117.

5. Secher M, Ritz P, Vellas B (2012) Nutrition and aging. In: Erdman JW, Macdonald IA, Zeisel SH, et al. Present knowledge in nutrition. 10th ed. International Life Sciences Institute; Wiley-Blackwell. 654-668.

6. Sahyoun NR, Jacques PF, Dallal GE, Russell RM (1997) Nutrition Screening Initiative Checklist may be a better awareness/educational too than a screening one. J Am Diet Assoc 97: 760-764.

7. White JV, Ham RJ, Lipschitz DA, Dwyer JT, Wellman NS (1991) Consensus of the Nutrition Screening Initiative: risk factors and indicators of poor nutritional status in older Americans. J Am Diet Assoc 91: 783-787.

8. Internal Revenue Service,Department of the Treasury, Employee Benefits Security Administration, Department of Labor, Centers for Medicare Medicaid Services, Department of, Health and Human Services (2013) Coverage of certain preventive services under the Affordable Care Act: Final rules. Fed Regist. 78:39869-39899.

9. Preston CM, Alexander M (2010) Prevention in the United States Affordable Care Act. J Prev Med Public Health 43: 455-458.

10. Chen C, Ackerly DC2 (2014) Beyond ACOs and bundled payments: Medicare's shift toward accountability in fee-for-service. JAMA 311: 673-674.

11. Federal Interagency Forum on Aging-Related Statistics (2012) Older Americans 2012: Key indicators of well-being. Washington, DC: U.S. Government Printing Office.

12. White JV (1996) The nutrition screening initiative: a 5-year perspective. NutrClinPract 11: 89-93.

13. European Commission DG Joint Research Centre (2014) The role of nutrition in active and healthy ageing for prevention and treatment of age-related diseases: Evidence so far. Luxembourg, European Union: JRC Science and Policy Reports.

14. Dwyer J (1994) Strategies to detect and prevent malnutrition in the elderly: The Nutrition Screening Initiative. Nutr Today. 29:14-24.

15. Incorporating nutrition screening and interventions into medical practice (1994)Washington, DC: Nutrition Screening Initiative.

16. The Nutrition Screening Initiative: Nutrition screening manual for professionals caring for older Americans. In: Washington, DC: Nutrition Screening Initiative.

17. Dwyer J (1991) Executive summary, screening older Americans' nutritional health: Current practices and future possibilities. Nutrition Screening Initiative.

18. White JV, Dwyer JT, Posner BM, Ham RJ, Lipschitz DA, et al. (1992) Nutrition Screening Initiative: development and implementation of the public awareness checklist and screening tools. J Am Diet Assoc 92: 163-167.

19. Posner BM, Jette AM, Smith KW, Miller DR (1993) Nutrition and health risks in the elderly: the Nutrition Screening Initiative. Am J Public Health 83: 972-978.

20. Benedict J, Wilson D, Snow G, Tyler, P, Remig, V, et al. (1995) Use of the Nutrition Screening Initiative to target and guide nutrition education efforts in Nevada. J Am Diet Assoc. 95.

21. Herndon AS (1995) Using the Nutrition Screening Initiative to survey the nutritional status of clients participating in a home delivered meals program. J Nutr Elder 14: 15-29.

22. Saunders MJ1 (1995) Incorporating the Nutrition Screening Initiative into the dental practice. Spec Care Dentist 15: 26-37.

23. Sinnett S, Bengle R, Brown A, Glass AP, Johnson MA, et al. (2010) The validity of Nutrition Screening Initiative DETERMINE Checklist responses in older Georgians. J Nutr Elder 29: 393-409.

24. Academy of Nutrition and Dietetics (2014)Nutrition screening. Nutrition Care Manual

25. Green SM1, Watson R (2006) Nutritional screening and assessment tools for older adults: literature review. J AdvNurs 54: 477-490.
26. Fried LP, Tangen CM, Walston J, Newman AB, Hirsch C, et al. (2001) Frailty in older adults: evidence for a phenotype. J Gerontol A BiolSci Med Sci 56: M146-156.

27. Morley JE, Vellas B, van Kan GA, Anker SD, Bauer JM, et al. (2013) Frailty consensus: a call to action. J Am Med DirAssoc 14: 392-397.

28. Tappenden K, Quatrara B, Parkhurst M, Malone A, Fanjiang G, et al. (2013) Critical role of nutrition in improving quality of care: An interdisciplinary call to action to address adult hospital malnutrition. J Acad Nutr Diet. 113:1219-1237.

29. Jena AB, Stevens W, McWilliams JM (2014) Turning evidence into practice under payment reform: the new frontier of translational science. J Gen Intern Med 29: 1542-1545.

30. Lakdawalla D, Snider JT, Perlroth DJ, LaVallee C, Linthicum MT, et al. (2013) Oral nutrition supplements' impact on hospital outcomes in the context of the Affordable Care Act and new Medicare reimbursement. The 35th annual meeting of the Society for Medical Decision Making.

31. Myers EF (2014) Is your perspective being reflected in the nutrition public policy landscape? Nutr Today. 49.

32. Kris-Etherton PM, Akabas SR, Bales CW, Bistrian B, Braun L, et al. (2014) The need to advance nutrition education in the training of health care professionals and recommended research to evaluate implementation and effectiveness. Am J Clin Nutr 99: 1153S-66S.

33. National Council of State Boards of Nursing (2013) NCLEX RN detailed test plan.

34. Samawi Z, Haras MS, Miller TL (2012) Age-appropriate health promotion education: roots firmly established in baccalaureate nursing pediatric rotation. J Pediatr Nurs 27: 44-49.

35. American Association of Colleges of Nursing (2011) The essentials of master's education in nursing.

36. Scott-Tilley D, Marshall-Gray P, Valadez A, Green A (2005) Integrating long-term care concepts into baccalaureate nursing education: the road to quality geriatric health care. J Nurs Educ 44: 286-290.

37. American Association of Colleges of Nursing (2010) Recommended baccalaureate competencies and curricular guidelines for the nursing care of older adults. A supplement to The Essentials of Baccalaureate Education for Professional Nursing Practice. 2010.

38. DiMaria-Ghalili RA, Mirtallo JM, Tobin BW, Hark L, Van Horn L, et al. (2014) Challenges and opportunities for nutrition education and training in the health care professions: intraprofessional and interprofessional call to action. Am J Clin Nutr 99: 1184S-93S.

39. Englert DM, Crocker KS, Stotts NA (1986) Nutrition education in schools of nursing in the United States. Part 1. The evolution of nutrition education in schools of nursing. JPEN J Parenter Enteral Nutr 10: 522-527.

40. Stotts NA, Englert D, Crocker KS, Bennum NW, Hoppe M (1987) Nutrition education in schools of nursing in the United States. Part 2: The status of nutrition education in schools of nursing. JPEN J Parenter Enteral Nutr 11: 406-411.

41. Morse W, Corcoran-Perry S (1993) Nutrition in nursing curricula: recent developments and recommendations. Nurs Outlook 41: 171-179.

42. Buckley KM (2003) Evaluation of classroom-based, Web-enhanced, and Web-based distance learning nutrition courses for undergraduate nursing. J Nurs Educ 42: 367-370.

43. Peake H, Stockely M, Frost G (2001) What nutritional support literature do hospital nursing staff require? J Hum Nutr Diet 14: 225-230.

44. Pradignac A, Petitdemange AM, Séry V, Hubsch A, Ben Ayed C, et al (2011) A nutritional education program for the nursing staff may improve hospitalized patients' nutritional assessment and management. e-SPEN. 6:e53-e58.

45. Boaz M, Rychani L, Barami K, Houri Z, Yosef R, et al. (2013) Nurses and nutrition: a survey of knowledge and attitudes regarding nutrition assessment and care of hospitalized elderly patients. J Contin Educ Nurs 44: 357-364. 
46. Yeung MS, Lapinsky SE, Granton JT, Doran DM, Cafazzo JA (2012) Examining nursing vital signs documentation workflow: barriers and opportunities in general internal medicine units. J Clin Nurs 21: 975-982.

47. Auerbach DI, Buerhaus PI, Staiger DO (2007) Better late than never: workforce supply implications of later entry into nursing. Health Aff (Millwood) 26: 178-185

48. Centers for Medicare \& Medicaid Services. (2003). Medicare and Medicaid programs; Hospital conditions of participation: Quality assessment and performance improvement. Fed Regist. 68:3435-3455.

49. JCAHO requires nutrition screening within 24 hours. Hosp Food Nutr Focus 12: 4-5.

50. The Academy of Nutrition and Dietetics (AND), Avalere (2014) Dialogue proceedings: Measuring the quality of malnutrition care in the hospitalized elderly patient.

51. Health Resources and Services Administration (HRSA) (2009) American Recovery and Reinvestment Act.

52. Vanek VW (2012) Providing nutrition support in the electronic health record era: the good, the bad, and the ugly. Nutr Clin Pract 27: 718-737.

53. Fossum M, Ehnfors M, Fruhling A, Ehrenberg A (2011) An evaluation of the usability of a computerized decision support system for nursing homes. Appl Clin Inform 2: 420-436.

54. Fossum M, Alexander GL, Ehnfors M, Ehrenberg A (2011) Effects of a computerized decision support system on pressure ulcers and malnutrition in nursing homes for the elderly. Int J Med Inform 80: 607-617.

55. Hoggle LB, Michael MA, Houston SM, Ayres EJ (2006) Electronic health record: where does nutrition fit in? J Am Diet Assoc 106: 1688-1695.

56. Conrad D, Hanson PA, Hasenau SM, Stocker-Schneider J (2012) Identifying the barriers to use of standardized nursing language in the electronic health record by the ambulatory care nurse practitioner. J Am Acad Nurse Pract 24: 443-451.

57. National Center for Health Statistics. (2001). Healthy People 2000 final review. Hyattsville, MD: Public Health Service.

58. U.S. Department of Health and Human Services. (2014). Older adults. Healthy People 2020.

59. Patient Protection and Affordable Care Act. HR3590, section 4103. Medicare coverage of annual wellness visit: Providing a personalized prevention plan.

60. Goetzel RZ, Staley P, Ogden L, Stange P, Fox J, et al. (2011) A framework for patient-centered health risk assessments: Providing health promotion and disease prevention services to Medicare beneficiaries.

61. Hughes C (2012) Medicare annual wellness visits: don't forget the health risk assessment. Fam Pract Manag 19: 11-14.

62. U.S. Preventive Services Task Force (2014) USPSTF A and B recommendations. U.S. Preventive Services Task Force Web site

63. U.S. Preventive Services Task Force (2013) High-priority evidence gaps for clinical preventive services: Third annual report to Congress November.

64. Jencks SF, Williams MV, Coleman EA (2009) Rehospitalizations among patients in the Medicare fee-for-service program. N Engl J Med 360: 1418-1428.

65. Krumholz HM (2013) Post-hospital syndrome--an acquired, transient condition of generalized risk. N Engl J Med 368: 100-102.

66. Friedmann JM, Jensen GL, Smiciklas-Wright H, McCamish MA (1997) Predicting early nonelective hospital readmission in nutritionally compromised older adults. Am J Clin Nutr 65: 1714-1720.

67. Rosen BS, Maddox PJ, Ray N (2013) A position paper on how cost and quality reforms are changing healthcare in America: focus on nutrition. JPEN J Parenter Enteral Nutr 37: 796-801.

68. Congressional Black Caucus Institute (CBCI). (2014) 21st Century Council 2014 Annual Report. 3.

69. White JV, Stotts N, Jones SW, Granieri E (2013) Managing postacute malnutrition (undernutrition) risk. JPEN J Parenter Enteral Nutr 37: 816-823.
70. U.S. Census Bureau (2014) 65+ in the United States: 2010. Washington, DC: U.S. Government Printing Office; 23-212.

71. Academy of Nutrition and Dietetics (AND) (2014) Background. Eatright.org

72. Henderson S, Princell CO, Martin SD (2012) The patient-centered medical home: this primary care model offers RNs new practice and reimbursement opportunities. Am J Nurs 112: 54-59.

73. The Academy of Nutrition and Dietetics (AND). (2014) RDs in the medical home model of care. Eatright.org

74. Ohio Dietetic Association (ODA). (2012) Medical nutrition therapy: Its place in the patient centered medical home.

75. Pereira GF, Bulik CM2, Weaver MA3, Holland WC4, Platts-Mills TF5 (2015) Malnutrition among cognitively intact, noncritically ill older adults in the emergency department. Ann Emerg Med 65: 85-91.

76. American Society for Parenteral and Enteral Nutrition (ASPEN) (2014) Malnutrition awareness week

77. Centers for Disease Control and Prevention (CDC). (2013) Falls - older adults.

78. Neelemaat F, Lips P, Bosmans JE, Thijs A, Seidell JC, et al. (2012) Shortterm oral nutritional intervention with protein and vitamin $\mathrm{D}$ decreases falls in malnourished older adults. J Am Geriatr Soc 60: 691-699.

79. Administration on Aging (AoA)( 2014) . Older Americans Act. Department of Health and Human Services

80. Administration on Aging (AoA)(2014). Historical evolution of programs for older Americans. Department of Health and Human Services.

81. Rep Bonamici S((2014) Older Americans Act Reauthorization Act of 2014. H R 4122.

82. Administration on Aging (AoA) (2014) AoA reauthorization targeted changes. Department of Health and Human Services

83. ACL Administration for Community Living. FY 2015 ACL budget table.

84. CRS Report for Congress. Older Americans Act: History of appropriations, FY 1996-FY 2004.

85. CRS Report for Congress. Funding for the Older Americans Act and other aging services programs.

86. Colello KJ (2012) Older Americans Act: Title III Nutrition Services Program. Food assistance programs and measures of food security in the United States. 65-80.

87. U.S. Government Accountability Office (2011) Older Americans Act: More should be done to measure the extent of unmet need for services. No. GAO-11-237.

88. National Black Nurses Association, Inc. (2012) Malnutrition resolution.

89. British Dietetic Association (2014) Nutritional screening, assessment and treatment. BDA The Association

90. British Dietetic Association (2012) The care of nutritionally vulnerable adults in community and all health and care settings. Policy statement.

91. British Association for Parenteral and Enteral Nutrition (2012) NSW overview: Establishing prevalence of malnutrition in adults on admission to care across the UK. BAPEN.org

92. Russell C, Aelia M (2012) Nutrition screening survey in the UK and republic of Ireland in 2011: A Report by the British Society for Parenteral and Enteral Nutrition (BAPEN).

93. Keller HH (2007) Promoting food intake in older adults living in the community: a review. Appl Physiol Nutr Metab 32: 991-1000.

94. Keller H. (2004) Identification of nutrition problems in older patients. Geri and Aging. 7:62-65.

95. Dietitians NZ (2014) Rest and residential care facilities. "Talk with" Series.

96. Trans Tasman Dietetic Wound Care Group (2011) Evidence based practice guidelines for the dietetic management of adults with pressure injuries. Dietitians Association of Australia, Dietitians NZ.

97. Watterson C, Fraser A, Banks M, Isenring E, Miller M, et al. (2009). Evidence based practice guidelines for the nutritional management of malnutrition in adult patients across the continuum of care. Nutr and Diet. 66:S1-S34. 
Citation: Watson K, Farrell M, Arensberg MB, Dwyer J (2014) Nutrition as a Vital Sign: Progress Since the 1990 Multidisciplinary Nutrition Screening Initiative and Opportunities for Nursing. J Nurs Care 4: 224. doi:10.4172/2167-1168.1000224

Page 15 of 15

98. Australian Government Department of Health. (2014) Health assessment for people aged 75 years and older. The Department of Health

99. Correia MI, Hegazi RA, Higashiguchi T, Michel JP, Reddy BR, et al. (2014) Evidence-based recommendations for addressing malnutrition in health care: an updated strategy from the feedM.E. Global Study Group. J Am Med Dir Assoc 15: 544-550.

100. Schindler K, Pernicka E, Laviano A, Howard P, Schütz T, et al. (2010) How nutritional risk is assessed and managed in European hospitals: a survey of 21,007 patients findings from the 2007-2008 cross-sectional nutritionDay survey. ClinNutr 29: 552-559.

101. Rice DP, Estes CL (1984) Health of the elderly: policy issues and challenges. Health Aff (Millwood) 3: 25-49.

102. Park E, Ruffing K, Van De Water PN (2011) Proposed cap on Federal spending would force deep cuts in Medicare, Medicaid, and Social Security. Center on Budget and Policy Priorities.

103. Ortman JM, Velkoff VA, Hogan H (2014) An aging nation: The older population in the United States. Washington, DC: U.S. Census Bureau. 25-1140.

104. National Center for Health Statistics (2014) Health, United States, 2013: With special feature on prescription drugs. Washington, DC: U.S. Government Printing Office.

105. U.S. Department of Commerce (1994) Americans with disabilities Bureau of the Census Statistical Brief.

106. Posner BM, Jette AM, Smith KW, Miller DR. (1993) Nutrition and health risks in the elderly: The Nutrition Screening Initiative. Am J Public Health. 83:972-978.

107. De Groot LCPGM, Beck AM, Schroll M, Van Staveren WA (1998) Evaluating the DETERMINE Your Nutritional Health Checklist and the Mini Nutrition Assessment as tools to identify nutritional problems in elderly Europeans. Eur J ClinNutr. 52:877-883.

108. Kuczmarski MF, Cooney TM (2008) Assessing the validity of the DETERMINE Checklist in a short-term longitudinal study. J Nutr Elder. 20:1-17.

109. Charlton KE, Kolbe-Alexander TL, Nel JH (2007) The MNA, but not the DETERMINE, screening tool is a valid indicator of nutritional status in elderly Africans. Nutr. 23:533-542.

110. Simons SD (1997) Nutrient intakes and DETERMINE Checklist scores of Hispanic elderly in south Texas. J Am Diet Assoc. 97:A86.

111. Mitchell DC, Smiciklas-Wright H, Friedmann JM, Jensen G (2002) Dietary intake assessed by the Nutrition Screening Initiative Level II Screen is a sensitive but not a specific indicator of nutrition risk in older adults. J Am Diet Assoc. 102:842-844.

112. Fox EA, Bonilla JE, Shields CE (1995) Comparison of DETERMINE Your Nutritional Health Checklist scores with nutrient-specific food frequency of rural elderly. J Am Diet Assoc. 95.

113. Melnik TA, Helferd SJ, Firmery LA, Wales K (1994) Screening elderly in the community: The relationship between dietary adequacy and nutritional risk. J Am Diet Assoc. 94:1425-1427.

114. Rush D (1993) Evaluating the Nutrition Screening Initiative. Am J Public Health. 83:944-945.
115. Levine BS, Wigren MM, Chapman DS, Kerner JF, Bergman RL, et al. (1993) A national survey of attitudes and practices of primary-care physicians relating to nutrition: Strategies for enhancing the use of clinical nutrition in medical practice. Am J ClinNutr. 57:115-119.

116. Hoffman B (2003) Health care reform and social movements in the United States. Am J Public Health. 93 :75-85.

117. Gallagher-Allred C (1993) Implementing nutrition screening and intervention strategies. Washington, DC: Nutrition Screening Initiative.

118. Hanisah R, Suzana S, Lee FS (2012) Validation of screening tools to assess appetite among geriatric patients. J Nutr Heal Aging. 16:660-665.

119. Wilson M-G, Thomas DR, Rubenstein LZ, Chibnall JT, Anderson S, et al. (2005) Appetite assessment: Simple appetite questionnaire predicts weight loss in community-dwelling adults and nursing home residents. Am J ClinNutr. 82:1074-1081.

120. Lawson CS, Campbell KL, Dimakopoulos I, Dockrell MEC (2012) Assessing the validity and reliability of the MUST and MST nutrition screening tools in renal inpatients. J Ren Nutr. 22:499-506.

121. Skipper A, Ferguson M, Thompson K, Castellanos VH, Porcari. (2012) Nutrition screening tools: An analysis of the evidence. JPEN J Parenter Enteral Nutr. 36:292-298

122. Isenring E, Bauer J, Banks M, Gaskill D (2009)The Malnutrition Screening Tool is a useful tool for identifying malnutrition risk in residential aged care. J Hum Nutr Diet. 22:545-550.

123. Wu ML, Courtney MD, Shortridge-Baggett LM, Finlayson K, Isenring EA (2012)Validity of the Malnutrition Screening Tool for older adults at high risk of hospital readmission. J Gerontol Nurs.38:38-45.

124. Isenring EA, Banks M, Ferguson M, Bauer JD (2012) Beyond malnutrition screening: Appropriate methods to guide nutrition care for aged care residents. J Acad Nutr Diet. 112:376-381.

125. Nestle Nutrition Institute (2012) Nutrition screening, as easy as M-N-A: A guide to completing the Mini Nutritional Assessment-Short Form (MNA-SF).

126. Omran ML, Morley JE (2000) Assessment of protein energy malnutrition in older persons, part I: History, examination, body composition, and screening tools. Nutr. 16:50-63.

127. Phillips MB, Foley AL, Barnard R, Isenring EA, Miller MD (2010) Nutritional screening in community-dwelling older adults: A systematic literature review. Asia Pac J ClinNutr. 19:440-449.

128. Beath H, Keller HH (2007) Nutrition screen showed good agreement when self- and interviewer administered. J Clin Epidemiol. 60:1085-1089.

129. Reimer HD, Keller HH, Maitland SB, Jackson J (2010) Nutrition screening index for older adults (SCREEN II৫) demonstrates sex and age invariance. J Nutr Elder. 29:192-210.

130. Keller HH, Goy R, Kane S. (2005) Validity and reliability of SCREEN II (Seniors in the Community: Risk Evaluation for Eating and Nutrition, version II). Eur J Clin Nutr. 59:1149-1157.

131. Nutrition Screening Initiative (1991) Report of Nutrition Screening 1: Toward a common view. Washington, DC: A Consensus Conference Sponsored by the Nutrition Screening Initiative. 